\title{
BOARD CHARACTERISTICS, COUNTRY OF ORIGIN, AND THE DECISION TO PARTICIPATE IN THE CDP'S WATER PROGRAMME
}

\author{
Bakhtiar Alrazi*, Inaliah Mohd Ali, Norhayati Mat Husin \\ *Department of Accounting, Universiti Tenaga Nasional, Sultan Haji Ahmad Shah Campus, 26700 \\ Muadzam Shah, Pahang, Malaysia
}

\begin{abstract}
This study examines the propensity of the world's largest companies to participate in the Carbon Disclosure Project (CDP) water programme. Drawing upon stakeholder theory, we assess the influence of board characteristics and country of origin on the decision of 748 largest companies from 42 countries to respond to the 2015 CDP water programme. Based on the binary logistic regression, we found that companies which participated in the survey have boards dominated by the independent directors, no specific environmental committee, and were domiciled in countries which placed greater emphasis on the information needs of the shareholders. We also found the evidence of companies operating in high water intensive industries to be more inclined towards participating in the survey. The findings provide tentative evidence to support the arguments of stakeholder theory.
\end{abstract}

Keywords: CDP water programme, board characteristics, country of origin, stakeholder theory.

\section{INTRODUCTION}

Water security is one of the most tangible and fastest-growing social, political and economic challenges faced today. A survey among of the World Economic Forum's global multistakeholder community in year 2014 ranked water crises as among the top 10 global risks likely to happen within 10 years and as the single most impactful risk on the society (WEF, 2015). This situation is alarming as prior to 2012, water crises did not even feature in the top 20 list. It is expected that, the demand for water in every sector to increase and analysis suggests that the world will face a 40\% global shortfall between forecast demand and available supply by 2030 . At present, more than one-third of the world's population-roughly 2.4 billion people-live in water-stressed countries, and by 2025 that proportion is expected to rise by two-thirds (Ceres, 2011). Ironically, the effects of climate change will exert further pressure on this problem causing either floods or droughts which in turn disrupt the supply of food and the availability of fresh water for consumption.

Recent years have seen a growing interest among the investors on environmental, social, and governance issues. One example is the establishment of Carbon Disclosure Project (CDP), a London-based not for profit organisation, which represents the interest of 827 investors with USD100 in assets. Over the years, CDP has built the most comprehensive collection of selfreported environmental data pertaining to climate, water, and forest encompassing over 5,600

*Corresponding author's email: Bakhtiar@uniten.edu.my 
companies and 533 cities. Investors requested for these information to make financial and other decisions about the companies. To achieve this, CDP has been inviting the world's largest companies, by size of market capitalisation, to participate in its annual surveys.

Unlike climate change, the interest in water and how companies are dealing with this issue is a recent phenomenon. CDP, for example, has started to invite companies to provide information voluntarily since year 2002. The water programme, however was first launched in year 2010. In a similar vein, there has been abundance of research focusing on carbon disclosure (see, for example, Alrazi et al., 2016; Luo and Tang, 2016; Liao et al., 2015; Luo et al., 2013; Luo et al., 2012; Rankin et al., 2011). However research into why companies engage in water reporting receives scant attention.

Thus, the aim of this research is to examine the factors influencing companies' decision to voluntarily report on their water policies, initiatives and performance to CDP. In particular, we assess the influence of board characteristics (independence, diversity, and environmental committee) and country of origin (legal system and strength of law enforcement) on the propensity of companies participating in the CDP water programme.

The study is pertinent for several reasons. First, it adds to the body of knowledge, in particular, the dearth of literature on water disclosure. In so doing, it enhances the discussion in the area of corporate governance (board characteristics) and this is done on an international setting (country of origin). Second, it helps us to understand the possible reasons for companies' voluntary participation in an environmental activity. It could also inform the investors of the characteristics of board of directors that promote environmental agenda. Finally, the results of this research address one of the major social concerns of our time, namely that of water scarcity, and the related company disclosure responses. Therefore, they will be of interest to regulators, managers, accountants, environmental groups, and researchers.

The remaining sections of this paper are structured as follows. Section 2.0 provides the review of related literature and hypotheses development. Section 3.0 presents the methods used for this research. Section 4.0 discusses the findings. Section 5.0 concludes the paper, highlights the limitations, and provides recommendation.

\section{LITERATURE REVIEW AND HYPOTHESES DEVELOPMENT}

Water scarcity imposes enormous challenges to businesses. These include disruption to operations from drought or flooding, declining water quality that required costly onsite pretreatment, increases in water prices, and fines and litigation relating to pollution incidents. In essence, for businesses, these problems impact their bottom line. Due to these escalating business impacts, water-related risks and opportunities are becoming a bigger focus among global investors. Thus, they have been seeking increased disclosure from companies on their water use and associated risks.

Businesses respond to these challenges in many ways. At present, there are over 130 companies worldwide that have committed to advance water stewardship, sanitation, and the Sustainable 
Development Goals - in partnership with the United Nations, governments, peers, civil society, and others. This is made through the CEO Water Mandate under the UN Global Compact in which signatories are committed to the six elements of water stewardship: direct operations, supply chain and watershed management, collective action, public policy, community engagement, and transparency. Businesses also have worked with World Business Council for Sustainable Development (WBCSD) to develop tools to help companies to better understand and manage their water-related challenges, and communicate effectively what they are doing about them. Some of the tools are industry-specific which are suitable for oil and gas, power utilities, and cement sectors. In 2011, Ceres, a U.S.-based coalition of investors, environmental groups, and other public interest organisations, partnered with WBCSD, Irbaris, and the IRRC Institute to publish a framework for water risk management. The framework emphasises four key areas, namely measurement, management, engagement, and disclosure. Additionally, there is a growing number of companies using CDP to guide their water management efforts. According to CDP (2015), the number of responding companies in 2010 was 150 and had increased to 1226 in 2015 (an increase of 700 percent). This trend is commensurate with the increase in the number of CDP Water programme signatories and the fact that water risk being regarded as one of the top three issues imposing the greatest impact to the society.

One common theme emerged from the abovementioned initiatives is disclosure. In essence, businesses are not only required to protect and preserve water, they also need to demonstrate their water stewardship. This can be done through corporate disclosure. Apart from participating in the CDP water programme, companies could disclose water-related information in their annual reports, stand-alone sustainability reports, or their own websites. There are also guidelines available for the companies to help them prepare the reports in a more consistent and comparable manner. The guidelines include CEO Water Mandates' Corporate Water Disclosure Guidelines and Global Reporting Initiative (GRI)'s sustainability reporting guidelines. According to KPMG (2015), GRI remains widely used by the world's largest companies, with three quarters (74 percent) of the G250 using the GRI framework (including in reporting on water-related information). Moreover, according to publication by KPMG International, GRI, UNEP and the Stellenbosch Business School (2016), a total of 400 sustainability reporting instruments in 64 countries were identified in year 2016 (as compared to 180 instruments identified in 44 countries in 2013 report) with $65 \%$ of them are considered as mandatory. This is particularly evident in Europe, Asia Pacific and Latin America.

Water disclosure is a sub-set of broader environmental disclosure. Other components include the disclosure related to materials, energy, biodiversity, emissions, and effluents and waste (GRI, 2013). In the past, the literature on environmental reporting has shown an increasing trend (Hahn and Kühnen, 2013). Recently, the increased awareness on the impact of climate change has brought about the interest in the disclosure of carbon and greenhouse gas information (see Ascui, 2014; Stechemesser and Guenther, 2012; and Hahn et al., 2015; for a review of literature on carbon disclosure/accounting). Of these studies, several have examined factors influencing the decision and quality of the disclosure to CDP Climate Change programme (Ben-Amar and McIlkenny, 2015; Ben-Amar et al., 2015; Depoers et al., 2016; Gonzalez-Gonzalez and Ramírez, 2016; Grauel and Gotthardt, 2016; Li et al., 2016; Liao et al., 2013, 2015; Luo et al., 2012; Peters and Romi, 2014; Reid and Toffel, 2009: Tang and Luo, 2014, 2016). 
Unlike carbon/climate change disclosure, the literature on water disclosure has received scant attention. Mohd. Remali et al. (2016) has conducted an exploratory research on the extent of water disclosure among top 10 Malaysian public listed companies based on market capitalisation and water risk profile. Overall, they found that the disclosure of such information in the annual report is still low. However, the findings are not generalisable as the sample is too small. Moreover, CDP since 2010 has conducted a survey among the world's largest companies and published the results on its website. However, it is still unclear as to what factors contributed to the decision of the companies to participate in the surveys since there is no statistical analysis conducted to test the relationships. It is of interest to examine whether factors found to be significant for CDP climate change programme in the previous literature are applicable for the water programme. Particularly relevant to this research is a study conducted by Liao et al. (2015) which examined the influence of board diversity, board independence, and the presence of environmental committee on the decision of 329 largest companies in the United Kingdom to participate in the CDP Climate Change programme for the year 2011. They found all the factors to be positive and significant.

Due to the limited attention being paid on water disclosure, this study intends to address this gap. Consistent with Liao et al. (2015) and other several studies (Depoers et al., 2016; GonzalezGonzalez and Ramírez, 2016; Luo et al., 2013), we use stakeholder theory to explain the relationship among the variables in this research.

\section{Stakeholder theory}

Clarkson (1995, p. 106) defines stakeholders as "[all] persons or groups that have, or claim, ownership, rights, or interests in a corporation and its activities, past, present, or future". He then distinguishes stakeholders into primary and secondary, with primary stakeholders (including shareholders, employees, customers, suppliers, government and communities) perceived as more critical to the survival of the business. In essence, the stakeholder groups are not only different in terms of the degree of impact they may have on the business and vice versa, but also in terms of the contents and format of the environmental reports addressing their concerns, and in the criteria they use to assess the appropriateness of corporate environmental behaviour.

Stakeholder theory attempts to articulate a fundamental question in a systematic way: which groups are stakeholders deserving or requiring management attention, and which are not?" (Mitchell et al, 1997). It acknowledges the dynamic and complex relationships between organisations and their stakeholders and that these relationships involve responsibility and accountability (Gray et al., 1996). Stakeholder analysis enables identification of those societal interest groups to whom the business might be considered accountable, and therefore to whom an adequate account of its activities would be deemed necessary. In this regard, if water information is important, then stakeholders would request for such information and companies in turn would provide the information (see also O'Higgins and Morgan, 2006 and Gago and Antolìn, 2004 for further discussion on stakeholder salience).

Stakeholder theory is relevant in the context of this research since the role of directors is to ensure that efforts and resources are spent towards the best interest of the company and its shareholders while ensuring that the interests of other stakeholders are not compromised (SC, 
2012). Therefore, the structure and composition of the board would determine the effective execution of this role. In essence, the more structured and diverse the board is, the greater the breadth and width of stakeholders be covered. Furthermore, previous studies have argued that the pressure faced by companies would be different across countries. Differences in the social, cultural, political, and economic settings of a country would shape the nature and intensity of stakeholders' expectations (Alrazi et al., 2016).

\section{Hypotheses development}

Following Liao et al. (2015), we examine the effect of board's gender diversity, board independence, and the presence of environmental committee on the companies' participation in CDP water programme. Furthermore, since this is an international comparative research, we include countries' legal origin and strength of law enforcement as the country variables. This is consistent with Simnett et al. (2009).

\section{Board independence}

One of the roles of board of directors is to ensure that the company's strategies promote sustainability (SC, 2012). Since independent directors do not hold any executive position in the company nor do they hold significant shareholding which will compromise their independence, it is expected that their presence on the board is to represent the interests of other stakeholders, they will have more influence on environmental reporting (Haniffa and Cooke, 2005). They will also improve the monitoring and controlling ability of the board over management (Fama and Jensen, 1983).

The extant literature found that companies with a higher proportion of independent directors tend to participate voluntarily in CDP climate change programme (Liao et al., 2015), have better environmental performance (De Villiers et al., 2011), and provide higher quality of community information. Based on these arguments, we hypothesise that,

$\mathrm{H}_{1}$ : Board independence is associated with the company's participation in the carbon disclosure project (CDP) water programme.

\section{Board's gender diversity}

Boards' gender composition is an important dimension of corporate governance because women and men are traditionally, culturally, and socially different. According to Hofstede's classification of national culture, masculinity "represents a preference in society for achievement, heroism, assertiveness and material rewards for success; while femininity stands for a preference for cooperation, modesty, caring for the weak and quality of life" (Hofstede, 2016). Gray (1988) further argued that as people are more caring and quality of life, people and the environment were given more emphasis, societies will tend to be more transparent including with socially related information.

Additionally, women are more committed, involved, and diligent (Huse and Solber, 2006) and less self-interest oriented (Coffee and Wang, 1998) that would create a good atmosphere in the 
board and improve the decision making process which ultimately lead to enhance board effectiveness enhancement. Due to their roles in society, it is also argued that women more concerned than men with environmental issues (Diamantopoulos et al., 2003) and more inclined to take actions to reduce perceived environmental risks (Bord and O'Connor, 1997). This gives a positive impact on organisation's socially responsible behaviour (Barako and Brown, 2008). Liao et al. (2015) and Ben-Amar et al. (2015) found that higher representation of female directors on the board tend to voluntarily participate in the CDP climate change programme. Thus, the following hypothesis is developed:

$\mathrm{H}_{2}$ : Board's gender diversity is associated with the company's participation in the carbon disclosure project (CDP) water programme.

\section{Environmental committee}

The presence of an environmental committee enables the organisation to monitor corporate environmental policy (Vafeas and Nikolaou, 2001), oversee its ecological impacts (Bansal and Roth, 2000; McKendall et al., 1999), and monitor and manage its relationship with key stakeholders (Elijido-Ten, 2007; Kent and Chan, 2009). It is also logical to anticipate that the committee would be more likely to see the importance of environmental reporting to their public, government, and other stakeholders (Rankin et al., 2011) and thus demand accountability from management (on environmental matters) so as to protect its reputation (McKendall et al., 1999).

Prior literature found the presence of an environmental committee to be associated with higher propensity of participating in CDP climate change programme (Liao et al., 2015; Peters and Romi, 2014) and more extensive and greater quality environmental reporting (Kent and Chan, 2009) and human resource reporting (Cowen et al., 1987) Therefore, the following hypothesis is developed:

$\mathrm{H}_{3}$ : Environmental committee is associated with the company's participation in the carbon disclosure project (CDP) water programme.

\section{Legal system}

The way businesses are being controlled and managed is partly determined by a country's legal system. This, in turn, defines the company-stakeholders relationship (Van der Laan Smith et al., 2005) and shapes the business culture (Simnett et al., 2009). Business culture can be broadly divided into stakeholder or shareholder orientated. In a stakeholder-orientated culture, a broad spectrum of stakeholders is assumed to have legitimate interests and influence on corporate activities (Simnett et al., 2009). Companies are considered to have social responsibility that goes beyond achieving economic efficiency (Kolk \& Perego, 2010; Van der Laan Smith et al., 2005). As such, corporate disclosure needs to consider the information needs of stakeholders other than shareholders. The nature of information can be both financial and non-financial. However, in a shareholder-orientated business culture, the influence of stakeholder groups, other than shareholders, is minimal, as the main purpose of a company is seen as shareholder wealth maximisation (Kolk \& Perego, 2010; Simnett et al., 2009; Van der Laan Smith et al., 2005). 
Following prior literature, it is assumed that companies domiciled in code law countries are more stakeholder-orientated, while those domiciled in common law countries are more shareholderorientated. Water, in general, is a stakeholder issue and at present information on consumption and discharges is not subjected to any disclosure requirement or accounting standard. Hence, companies publish it on a voluntary basis to satisfy the information needs of the stakeholders. Consistent with stakeholder theory and the findings of Kolk and Perego (2010) and Simnett et al. (2009) who found significant influence of countries' legal system on sustainability reporting, it is hypothesise that;

$\mathrm{H}_{4}$ : Countries' legal system is associated with the company's participation in the carbon disclosure project (CDP) water programme.

\section{Strength of law enforcement}

As stated earlier, environmental disclosure has remained largely voluntary across the world. Mandatory reporting, if any, usually pertains to a single issue with limited disclosure requirements (KPMG et al., 2015). Nevertheless, Walden and Schwartz (1997) argue that the degree of public pressure (for environmental responsibility) is greater in an environment where there is a greater likelihood of additional legislations and sanctions, increased regulatory oversight, and dissatisfaction of the general public or a group of public. Here, regulators, customers, and non-governmental organisations promoting sustainability become the key stakeholders.

Prior literature has also found that the extent of regulatory enforcement has also been associated with lower incidence of corporate environmental lawsuits (Kassinis and Vafeas, 2002), company decisions to have sustainability reports assured by a third party organisation (Simnett et al., 2009), and voluntary participation in the CDP climate change programme (Reid and Toffel, 2009). Consistent with the argument of stakeholder theory, it is expected that companies domiciled in countries with a strong law enforcement environment will be more likely to voluntarily participate in the CDP water programme. Thus, we hypothesise that;

$\mathrm{H}_{5}$ : Countries' strength of law enforcement is associated with the company's participation in the carbon disclosure project (CDP) water programme.

\section{RESEARCH METHODS}

\section{Population and sample}

The population of this research consists of all companies invited to participate in the 2015 CDP water programme. According to CDP (2015), a total of 1,073 world's largest public listed companies were invited to participate in its survey. The companies were deemed to have high water vulnerability hence expected to provide disclosure as to how they manage risks, and seize opportunities, related to water. A further assessment was made on these companies to ensure the availability of data for the purpose of testing the hypotheses. The final sample comprises 748 companies from 42 different countries. Other companies (i.e. 325) were removed from the 
sample due to unavailability of complete and/or English-based annual reports and there was no other means of obtaining the required data. Although not tabulated here, the majority of the sample are from US (26.3\%), Japan (15\%), UK (8.7\%), Australia (6.6\%), and South Africa $(5.9 \%)$. Additionally, materials (23\%), consumer directory (17\%), and industrials (14\%) represent the industries with the highest representatives in the sample.

\section{Data collection methods}

Data were collected using the secondary method. The dependent variable is represented by the decision of companies to participate in the 2015 CDP water programme which is extracted from CDP (2015). Data for board characteristics were collected from the annual reports for the year 2014 or the company websites. In regards to country of origin, data were collected from the CIA (2016) and World Bank (2016). The classification of industry is based on CDP (2015).

\section{Measurement of variables}

Table 1 below summarises the measurement of variables used in this research.

\begin{tabular}{|l|l|l|l|}
\hline No & Variables & Measurement & Source \\
\hline 1 & CDP ${ }_{\text {WATER }}$ & $\begin{array}{l}1=\text { if the company responded to the CDP water programme } \\
\text { survey; } 0 \text { if otherwise }\end{array}$ & CDP (2015) \\
\hline 2 & BIND & $\begin{array}{l}\text { The percentage of independent non-executive directors out } \\
\text { of total directors }\end{array}$ & Annual reports \\
\hline 3 & BDIV & The percentage of female directors out of total directors & Annual reports \\
\hline 4 & BCOMM & $\begin{array}{l}1=\text { if there is board committee for environmental issues; } 0 \text { if } \\
\text { otherwise }\end{array}$ & Annual reports \\
\hline 5 & LEGAL & $\begin{array}{l}1=\text { companies domiciled in code law countries; } 0= \\
\text { companies domiciled in common law countries }\end{array}$ & CIA (2016) \\
\hline 6 & LAW & $\begin{array}{l}\text { Countries' rule of law } \\
1=\text { Companies operating in high water intensive industries; } \\
0 \text { if otherwise }\end{array}$ & CDP (2015); Ceres (2011) \\
\hline 7 & $I N D$ &
\end{tabular}

Table 1: Measurement of variables

\section{Regression model}

Hence, the regression model for this research is as follows:

$C D P_{\text {WATER }}=\beta_{0}+\beta_{1} B I N D+\beta_{2} B D I V+\beta_{3} B C O M M+\beta_{4} L E G A L+\beta_{5} L A W+\beta_{6} I N D+\varepsilon$

The definition for each variable is available in Table 1. Logistic regression is used to test the hypotheses.

\section{FINDINGS AND ANALYSIS}

This section presents the findings from the descriptive statistics, correlation analysis, and logistic regression analysis. 


\section{Descriptive statistics}

Table 2 depicts the descriptive statistics for the variables used in estimation. Based on the table, 44 percent of the sample companies participated in the CDP water programme. Additionally, about one-half of the directors in the sample companies are independent non-executive directors (mean $B I N D=46 \%$ ). However, female directors only constituted $16 \%$ of the directors. The majority of the companies did not have any specific board level committee to monitor their environmental performance $(B C O M M=37 \%)$.

\begin{tabular}{|c|c|c|c|c|c|}
\hline \multicolumn{6}{|c|}{ Panel A: Descriptive statistics of continuous variables used in estimation } \\
\hline Variable & Mean & Median & Q1 & Q3 & Std dev \\
\hline$B I N D$ & 46.20 & 46.41 & 20.36 & 71.07 & 29.115 \\
\hline$B D I V$ & 16.39 & 16.67 & 7.14 & 25.00 & 13.154 \\
\hline$L A W$ & 1.41 & 1.62 & 1.47 & 1.89 & 0.669 \\
\hline \multicolumn{6}{|c|}{ Panel B: Distribution of categorical variables } \\
\hline & \multicolumn{3}{|c|}{1} & \multirow[b]{2}{*}{$N$} & \\
\hline & Variable & $N$ & $\%$ & & $\%$ \\
\hline & $C D P_{W A T E R}$ & 329 & 44.0 & 419 & 56.0 \\
\hline & $B C O M M$ & 278 & 37.2 & 470 & 62.8 \\
\hline & $L E G A L$ & 392 & 52.4 & 356 & 47.6 \\
\hline & $I N D$ & 143 & 19.1 & 605 & 80.9 \\
\hline
\end{tabular}

This table presents descriptive statistics of the dependent and independent variables used in correlation and regression analyses. Statistics are presented for the full sample of 748 companies. All variables are defined in Table 1.

Table 2: Descriptive statistics of continuous variables

In terms of country of origin, there is a balanced composition between companies domiciled in code law countries and common law countries (with $52 \%$ and $48 \%$, respectively) and, on average, they are from a strong law enforcement environment in which the average $L A W$ of 1.41 is higher than the world's average of 0.00 (World Bank, 2016). Finally, about $20 \%$ of the sample companies were operating in the high water intensity industries. In this research, following the classification by Ceres (2011), utilities and energy industries are regarded as high water risk industries.

\section{Correlation analysis}

Correlation analysis was conducted to determine whether there is a multicollinearity problem that could influence the regression analysis. Table 3 provides the results of the correlation statistics with Pearson above the diagonal and Spearman's rho, below. This is a two-tailed test of significance. There appears to be no serious multicollinearity issues among the independent variables. According to Field (2013), a coefficient correlation of greater than, or equal to, $(\geq)$ 0.80 indicates there is cause for concern. Based on the table below, the highest coefficient is $0.461(p=0.000)$ which is between $L E G A L$ and $L A W$. 


\begin{tabular}{lllllllc}
\hline & $C D P_{\text {WATER }}$ & \multicolumn{1}{c}{ BIND } & \multicolumn{1}{c}{ BDIV } & BCOMM & \multicolumn{1}{c}{ LEGAL } & \multicolumn{1}{c}{ LAW } & IND \\
\hline CDP $P_{\text {WATER }}$ & - & 0.053 & 0.068 & $0.166^{* *}$ & 0.062 & 0.039 & $-0.129^{* *}$ \\
BIND & 0.053 & - & $0.085^{*}$ & 0.003 & $-0.207^{* *}$ & $0.108^{* *}$ & $0.193^{* *}$ \\
BDIV & $0.073^{*}$ & $0.085^{*}$ & - & 0.018 & $-0.155^{* *}$ & $0.090^{*}$ & -0.044 \\
BCOMM & $0.166^{* *}$ & 0.003 & 0.030 & - & 0.007 & -0.023 & 0.027 \\
LEGAL & 0.062 & $-0.215^{* *}$ & $-0.205^{* *}$ & 0.007 & - & $-0.391^{* *}$ & $-0.081^{*}$ \\
LAW & -0.021 & $0.229^{* *}$ & $0.205^{* *}$ & -0.066 & $-0.461^{* *}$ & - & $-0.177^{* *}$ \\
$I N D$ & $-0.129^{* *}$ & $0.192^{* *}$ & -0.037 & 0.027 & $-0.081^{*}$ & $-0.086^{*}$ & - \\
\hline
\end{tabular}

This table presents the correlation statistics for the dependent and independent variables used in multivariate analyses. Statistics are presented for the full sample of 748 companies. All variables are defined in Table $1 . *$ and ** represent significance levels (two-tailed) at 5 percent and 1 percent, respectively.

Table 3: Correlation statistics for dependent and independent variables

\section{Regression analysis}

The results of the logistic regression are presented in Table 4 . The reported pseudo- $R^{2}$, namely Cox \& Snell $R^{2}$ and Nagelkerke $R^{2}$ are 0.062 and 0.083 , respectively. Based the table, only BIND shows finding that is consistent with the hypothesis. It indicates that companies with higher proportion of independent directors had greater proclivity to respond to the CDP water programme. As argued earlier, the presence of independent directors on the board is as a proxy for the interest of stakeholders other than shareholders. BCOMM is significant at 0.01 level, however in the opposite direction. This is inconsistent with the findings of Liao et al. (2015) and Peters and Romi (2014) who found that the presence of environmental committee increases the likelihood companies participating in CDP climate change programme.

In terms of country of origin, $L E G A L$ is significant $(p=0.015)$. The negative coefficient is suggesting that companies from the common law countries tend to participate in the CDP water programme. Even though it is code law countries that are argued to be stakeholder-oriented, the fact that the raison d'etre of CDP establishment is to serve investors (CDP, 2015) may have induced greater pressure for companies from the common law countries to be more forthcoming in this issue. This is consistent with the findings of Luo et al. (2012), Luo et al. (2013), and Graul and Gotthardt (2016).

\begin{tabular}{lcrll}
\hline Variables & Expected sign & $\beta$ & Wald Statistics & Sig. \\
\hline$B I N D$ & + & 0.06 & 5.583 & $0.018^{*}$ \\
$B D I V$ & + & 0.10 & 2.962 & 0.085 \\
$B C O M M$ & + & -0.733 & 21.774 & $0.000^{* *}$ \\
LEGAL & + & -0.414 & 5.901 & $0.015^{*}$ \\
LAW & + & 0.165 & 1.676 & 0.195 \\
$I N D$ & + & 0.758 & 12.973 & $0.000^{* *}$ \\
Constant & & -0.913 & 9.492 & $0.002^{* *}$ \\
Observations & & 748 & & \\
Likelihood & & 978.116 & & \\
Cox \& Snell $R^{2}$ & & 0.062 & & \\
Nagelkerke $R^{2}$ & & 0.083 & & \\
\hline
\end{tabular}

[Type here] 
All variables are defined in Table $1 . *$ and $* *$ represent significance levels (two-tailed) at 5 percent and 1 percent, respectively.

Table 4: Logistic regression analysis

Consistent with the prediction, IND is positive and significant $(p=0.002)$ implying that companies operating in the high water intensive industries have greater proclivity to engage in water reporting. This is consistent with Luo et al. (2012). Additional analysis was also conducted to re-classify the industries to include industrials, materials, consumer directory, and consumer staples as high water intensive (they are considered 'medium' in CDP, 2015). Although not tabulated here, IND remains positive and significant $(\mathrm{p}=0.000)$.

$B D I V$ and $L A W$ are not significant, despite the signs show the predicted direction. Gender of the board members do not influence the companies' decision on CDP water programme. This is inconsistent with the findings of Ben-Amar et al. (2015). As shown in Table 2, the average of $B D I V$ is $16 \%$, indicating that male directors still dominate the board. The result for $L A W$ suggests that the strength of law enforcement in a country does not have significant influence on companies' decision to participate in CDP water programme. This is consistent with Alrazi et al. (2016).

\section{CONCLUSION}

This study examines the propensity of 748 global largest companies to respond to CDP water programme in year 2014. The number of responding companies is considered high with $44 \%$. Using stakeholder theory as the underlying framework, we found that companies that tend to participate in the survey have greater proportion of independent directors and no specific board level committee on environmental issues, domiciled in common law countries, and operated in the high water sensitive industries.

There are several limitations inherent in this study. First, the participation in the CDP water programme as the measure for dependent variable might be too crude. It does not capture the quantity and quality of the information being disclosed in such a survey. Additionally, we did not consider cases in which companies participated but did not allow the survey to be made publicly available on the CDP website. Hence, future studies may want to consider these issues (see BenAmar and McIlkenny, 2015).

Second, we only examined three board characteristics and two country of origin variables. As evidenced by the $R^{2}$ values, they are low suggesting that there are other variables that could explain the variation in reporting decision. Liao et al. (2014) for example included board size, board meeting, CEO compensation, and directors' ownership. Ben-Amar and McIlkenny (2015) used overall board effectiveness as a proxy for board characteristic (see also Rankin et al., 2011). Country factors that can be tested include environmental performance/regulations (Alrazi et al., 2016; Graul and Gotthardt, 2016; Luo et al., 2012), culture (Luo and Tang, 2016), and economic development (Luo et al., 2013).

Moreover, we only examined industry as company characteristic but not company size, multinational orientation (Graul and Gotthardt, 2016), financial risk, listing status, ownership

[Type here] 
concentration (Gonzalez-Gonzalez and Ramírez, 2016), degree of resource availability (Luo et al., 2013), and internal organisation system factors (Rankin et al., 2011).

\section{REFERENCES:}

Alrazi, B., De Villiers, C., \& Van Staden, C.J., (2016), The environmental disclosures of the electricity generation industry: a global perspective, Accounting and Business Research, 46(6), 665-701.

Ascui, F. (2014). A review of carbon accounting in the social and environmental accounting literature: what can it contribute to the debate? Social and Environmental Accountability Journal, 34(1), 6-28. DOI: 10.1080/0969160X.2013.870487

Bansal, P. \& Roth, K. (2000), Why companies go green: A model of ecological responsiveness, Academy of Management Journal, 43(4), 717-736. DOI: 10.2307/1556363

Ben-Amar, W. \& McIlkenny, P. (2015). Board effectiveness and the voluntary disclosure of climate change information, Business Strategy and the Environment, 24(8), 709-714. DOI: $10.1002 /$ bse. 1840

Ben-Amar, W., Chang, M. \& McIlkenny, P. (2015), Board gender diversity and corporate response to sustainability initiatives: Evidence from the Carbon Disclosure Project, Journal of Business Ethics, July, 1-15. DOI: 10.1007/s10551-015-2759-1

CDP (2015). Accelerating action: CDP Global Water Report 2015, Carbon Disclosure Project: London. Retrieved from: https://www.cdp.net/CDPResults/CDP-Global-Water-Report2015.pdf

Ceres (2011). The Ceres Aqua Gauge: A Framework for 21st Century Water Risk Management: Retrieved from: https://www.ceres.org/resources/reports/aqua-gauge

CIA (2016). The World Factbook: Legal System. Central Intelligence Agency: Washington. Retrieved from: https://www.cia.gov/library/publications/the-worldfactbook/fields/2100.html

Clarkson, M.B.E., (1995), A stakeholder framework for analyzing and evaluating corporate social performance, Academy of Management Review, 20(1), 92-117. DOI: http://www.jstor.org/stable/258888

Cowen, S. S., Ferreri, L. B., \& Parker, L. D. (1987), The impact of corporate characteristics on social responsibility disclosure: A typology and frequency-based analysis, Accounting, Organizations and Society, 12(2), 111-122. DOI: 10.1016/0361-3682(87)90001-8

De Villiers, C., Naiker, V., \& Van Staden, C.J., (2011), The effect of board characteristics on firm environmental performance, Journal of Management, 37(6), 1636-1663. DOI: $0.1177 / 014920631141150$

Depoers, F., Jeanjean, T. \& Jérôme, T. (2016), Voluntary disclosure of greenhouse gas emissions: Contrasting the Carbon Disclosure Project and corporate reports, Journal of Business Ethics, 134(3), 445-461. DOI: 10.1007/s10551-014-2432-0

Elijido-Ten, E. (2007), Applying stakeholder theory to analyze corporate environmental performance: Evidence from Australian listed companies, Asian Review of Accounting, 15(2), 164 - 184. DOI: 10.1108/13217340710823378

Fama, E.F. \& Jensen, M.C., (1983), Separation of ownership and control, The Journal of Law \& Economics, 26(2), 301-325. DOI: http://www.jstor.org/stable/725104 
Field, A. (2013), Discovering Statistics using IBM SPSS Statistics (4th ed.), SAGE Publications: London.

Gago, R.F., \& Antolìn, M.N., (2004), Stakeholder salience in corporate environmental strategy, Corporate Governance, 4 (3), 65-76. DOI: 10.1108/14720700410547512.

Gonzalez-Gonzalez, J.M. \& Ramírez, C.Z. (2016), Voluntary carbon disclosure by Spanish companies: an empirical analysis, International Journal of Climate Change Strategies and Management, 8(1), 57 - 79. DOI: 10.1108/IJCCSM-09-2014-0114

Graul, J. \& Gotthardt, D. (2016). The relevance of national contexts for carbon disclosure decisions of stock-listed companies: a multilevel analysis, Journal of Cleaner Production, 133, 1204-1217. DOI: $\underline{10.1016 / j . j c l e p r o .2016 .05 .182}$

Gray, R., Owen, D., \& Adams, C., (1996). Accounting \& Accountability - Changes and Challenges in Corporate Social and Environmental Reporting. Prentice Hall Europe: Hertfordshire.

Gray, S. (1988). Towards a theory of cultural influence on the development of accounting systems internationally, ABACUS, 24(1), 1-15. DOI: 10.1111/j.1467-6281.1988.tb00200.x

GRI (2013). G4 Sustainability Reporting Guidelines: Reporting Principles and Standard Disclosures, Global Reporting Initiative: Amsterdam. Retrieved from: https:/www.globalreporting.org/resourcelibrary/GRIG4-Part1-Reporting-Principles-andStandard-Disclosures.pdf

Hahn, R. \& Kühnen, M. (2013), Determinants of sustainability reporting: a review of results, trends, theory, and opportunities in an expanding field of research, Journal of Cleaner Production, 59, 5-21. DOI: 10.1016/j.jclepro.2013.07.005

Hahn, R., Reimsbach, D. \& Schiemann, F. (2015). Organizations, climate change, and transparency: Reviewing the literature on carbon disclosure, Organization \& Environment, 28(1), 80-102. DOI: $10.1177 / 108602661557554$

Haniffa, R.M. \& Cooke, T.M. (2006). The impact of culture and governance on corporate social reporting, Journal of Accounting and Public Policy, 24(5), 391-430. DOI: 10.1016/j.jaccpubpol.2005.06.001

Hofstede, G. (2016), National culture, itim International: Helsinki. Retrieved from: https://geerthofstede.com/national-culture.html

Kassinis, G., \& Vafeas, N. (2002), Corporate boards and outside stakeholders as determinants of environmental litigation, Strategic Management Journal, 23, 399-415. DOI:10.1002/smj.230

Kent, P., \& Chan, C. (2009), Application of stakeholder theory to corporate environmental disclosures, Corporate Ownership \& Control, 7(1), 399-414. DOI: http://epublications.bond.edu.au/business pubs/258/

Kolk, A., \& Perego, P. (2010), Determinants of the adoption of sustainability assurance statements: an international investigation, Business Strategy and the Environment, 19, 182 198. DOI: $10.1002 /$ bse. 643

KPMG (2015). The KPMG Survey of Corporate Responsibility Reporting 2015. KPMG International Cooperative: Netherlands. Retrieved from: https://assets.kpmg.com/content/dam/kpmg/pdf/2015/11/kpmg-international-survey-ofcorporate-responsibility-reporting-2015.pdf

KPMG, GRI, UNEP, \& USB (2016). Carrots \& Sticks: Global Trends in Sustainability Reporting Regulation and Policy. Retrieved from: https://assets.kpmg.com/content/dam/kpmg/pdf/2016/05/carrots-and-sticks-may-2016.pdf

[Type here] 
Li, D., Huang, M., Ren, S., Chen, X., \& Ning, L. (2016). Environmental legitimacy, green innovation, and corporate carbon disclosure: Evidence from CDP China 100, Journal of Business Ethics, May, 1-16. DOI: 10.1007/s10551-016-3187-6

Liao, L., Luo, L., \& Tang, Q. (2015), Gender diversity, board independence, environmental committee, and greenhouse gas disclosure, The British Accounting Review, 47(4), 409424. DOI: $10.1016 /$ j.bar.2014.01.002

Luo L., Lan Y.C., \& Tang, Q., (2012), Corporate incentives to disclose carbon information: Evidence from the CDP Global 500 Report, Journal of International Financial Management and Accounting, 23, 93-120. DOI: 10.1111/j.1467-646X.2012.01055.X

Luo, L. \& Tang, Q. (2016). Determinants of the quality of corporate carbon management systems: An international study, The International Journal of Accounting, 51(2), 275-305. DOI: $10.1016 /$ j.intacc.2016.04.007

Luo, L., Tang, Q., \& Lan, Y.C., (2013). Comparison of propensity for carbon disclosure between developing and developed countries: A resource constraint perspective, Accounting Research Journal, 26(1), 6-34. DOI: 10.1108/ARJ-04-2012-0024

Luo, L.L. \& Tang, Q. (2016), Does national culture influence corporate carbon disclosure propensity?, Journal of International Accounting Research: Spring, 15(1), 17-47. DOI: 10.2308/jiar-51131

McKendall, M., Sanchez, C. \& Sicilian, P., (1999), Corporate governance and corporate illegality: The effects of board structure on environmental violations, The International Journal of Organizational Analysis, 7(3), 201-223. DOI: 10.1108/eb028900

Mitchell, R.K., Agle, B.R., and Wood, D.J., (1997). Toward a theory of stakeholder identification and salience: defining the principle of who and what really counts, Academy of Management Review, 22 (4), 853-886. DOI: http://www.jstor.org/stable/259247

Mohd. Remali, A.R., Mohd. Ali, I., Mat Husin, N., \& Alrazi, B., (2016), An exploratory study on water reporting among top Malaysian public listed companies, Procedia Economics and Finance, 35, 64-73. DOI: 10.1016/S2212-5671(16)00010-1

O'Higgins, E.R.E. \& Morgan, J.W. (2006), Stakeholder salience and engagement in political organisations: Who and what really counts? Society and Business Review, 1(1), 62-76. DOI: $10.1108 / 17465680610643355$

Peters, G.F. \& Romi, A.E. (2014). Does the voluntary adoption of corporate governance mechanisms improve environmental risk disclosures? Evidence from greenhouse gas emission accounting. Journal of Business Ethics, 125(4), 637-666. DOI: 10.1007/s10551013-1886-9

Rankin, M., Windsor, C., \& Wahyuni, D., (2011). An investigation of voluntary corporate greenhouse gas emissions reporting in a market governance system: Australian evidence, Accounting, Auditing \& Accountability Journal, 24 (8), 1037-1070. DOI: $10.1108 / 09513571111184751$

Reid, E.M. \& Toffel, M.W. (2009), Responding to public and private politics: Corporate disclosure of climate change strategies, Strategic Management Journal, 30, 1157-1178. DOI: $10.1002 / \mathrm{smj} .796$

SC (2012). Malaysian Code on Corporate Governance. Securities Commission: Kuala Lumpur. Retrieved from: https://www.sc.com.my/wp-content/uploads/eng/html/cg/cg2012.pdf

Simnett, R., Vanstraelen, A., \& Chua, W. F. (2009). Assurance on sustainability reports: An international comparison. The Accounting Review, 84(3), 937-967. DOI: 10.2308/accr.2009.84.3.937

[Type here] 
Stechemesser, K. \& Guenther, E. (2012). Carbon accounting: a systematic literature review, Journal of Cleaner Production, 36, 17-38. DOI: 10.1016/j.jclepro.2012.02.021

Vafeas, N. \& Nikolaou, V. (2001). The association between corporate environmental and financial performance, Advances in Public Interest Accounting, 8, 195-214. DOI: 10.1016/S1041-7060(01)08010-5

Van der Laan Smith, J., Adhikari, A., \& Tondkar, R. H. (2005), Exploring differences in social disclosures internationally: A stakeholder perspective, Journal of Accounting and Public Policy, 24, 123-151. DOI:10.1016/j.jaccpubpol.2004.12.007

WEF (2015). Global Risk 2015, 10th Edition, World Economic Forum: Geneva. Retrieved from: http://www3.weforum.org/docs/WEF Global Risks 2015 Report15.pdf

World Bank (2016). Worldwide Governance Indicators. The World Bank Group: Washington. Retrieved from: http://info.worldbank.org/governance/wgi/index.aspx\#home

[Type here] 